\title{
Sagan á bak við salernis-innlagnir á Landspítala
}

Landspítali er stærsta heilbrigðisstofnun landsins og í pví samhengi ætla ég að leyfa mér hér að kalla hann hjarta íslenska heilbrigðiskerfisins. Spítalinn er góður vinnustaður og par vinnur fagfólk á heimsmælikvarða. Ég heyri oft pakkláta sjúklinga og aðstandendur hrósa starfsfólki fyrir frábæra pjónustu sem veitt er pó að upp á vanti með húsakost og vinnuaðstöðu. Prátt fyrir sterkan slagkraft á Landspítali bersýnilega í vaxandi erfiðleikum. •að gengur erfiðlega að halda markmið um lágmarksbiðtíma eftir aðgerðum og daglega, á undanförnum mánuðum, dvelja frá 15 til 25 sjúklingar á bráðamóttöku sem bíða eftir að komast í rúm á legudeild. Sú bið getur tekið upp í prjá sólarhringa. ${ }^{1}$ Vegna pessa álags á bráđamóttöku hefur spítalinn starfað eftir viðbragðsstigi 2 sem pýðir að framkvæmdastjóri ákveður að innlagnir umfram legurými verði í hámarki á hverri deild. Lyflækningasvið spítalans hefur brugðist við pessu ástandi með pví að manna sérstakt hreyfiteymi lækna sem vinnur við tilbúnar vinnuaðstæður á bráðamóttöku og sinnir uppvinnslu og meðferð pessara sjúklinga. Bráðahjúkrunarfræðingar hlaupa hratt og sinna bráðveikum milli pess sem peir sinna innlögðum sjúklingum sem ekki komast á legudeild.

Álagið á bráðamóttöku spítalans hefur verið viðvarandi hátt og er sívaxandi. Ein af orsökum vandans hefur verið skilgreind og nefnd fráflæði-vandi. Á síðasta ári biðu á vegum Landspítala að jafnaði um 90-100 einstaklingar, með sampykkt færni- og heilsumat, eftir varanlegri búsetu á hjúkrunarheimili. Frá pví í september hefur peim einstaklingum fjölgað í um 130. ${ }^{1}$ Embætti landlæknis lýsti nýlega yfir pungum áhyggjum af pessu ástandi. 362 einstaklingar biðu eftir hjúkrunarrými í byrjun árs 2018 og er pað 60\% fjölgun frá pví í ársbyrjun 2014.

Mig langar að staldra aðeins við orðið fráflæðivandi. Orðið vísar til pess að erfiðlega gengur að útskrifa aldraða einstaklinga sem lokið hafa bráðameðferð. Pessum einstaklingum er pannig sinnt á röngu pjónustustigi og pað skapar tregðu par sem rúm á legudeildum losna ekki með eðlilegum hætti fyrir nýja sjúklinga. Orðið fráflæði-vandi finnst mér vera vont orð par sem pað elur á aldursfordómum. Auðvitað eru pað ekki færniskertir aldraðir einstaklingar sem eiga sökina á vanda Landspítala með pví að hindra fráflæði. Petta ástand er einungis birtingarmynd kerfisvanda í heilbrigðiskerfinu. Kerfið hefur ekki undirbúið sig á heildstæðan hátt fyrir öldrun pjóðarinnar. Ekki hefur orðið fjölgun á hjúkrunarrýmum í takt við aukinn fjölda aldraðra og heildstæða stefnu um heilbrigðis- og félagspjónustu aldraðra hefur vantað.

Önnur mikilvæg áskorun sem sjúkrahúsið glímir við er mönnunarvandi hjá flestum fagstéttum og pá sérstaklega skortur á hjúkrunarfræðingum og sjúkraliðum. Mér telst til að sjúkrahúsið hafi á pessu ári lokað samtals 32 legurýmum á lyf- og skurðlækningadeildum vegna manneklu. ${ }^{1}$ Pað vantar hjúkrunarfræðinga til að fullmanna vaktir á Hjartagátt og nú stendur til að færa pá starfsemi yfir á bráðamóttökuna í Fossvogi.

Par sem ég í upphafi pessa pistils leyfði mér að kalla Landspítala hjarta heilbrigðiskerfisins ætla ég hér einnig að leyfa mér að halda pví fram að heilbrigðiskerfið glími við hjartabilun. Til að ná tökum á ástandinu fyrir alvöru verðum við að forgangsraða og ráðast á rætur vandans. Uppbygging hjúkrunarrýma er nauðsynleg en verður langt í frá eina lausnin á vaxandi fjölda aldraðra á Íslandi. Við verðum að hugsa eftir nýjum leiðum og getum lært af árangursríkum verkefnum annarra pjóða.

Í júní 2017 kom til Íslands Mark Britnell stjórnarformaður KPMG Global Health Care, en hópur á vegum fyrirtækisins gerði úttekt á íslenska heilbrigðiskerfinu. Britnell er reyndur stjórnandi úr breska heilbrigðiskerfinu og starfar sem ráðgjafi fyrir stjórnendur heilbrigðiskerfa. Í erindi sem hann hélt tjáði hann sig um íslenska heilbrigðiskerfið. ${ }^{2}$ Hann talaði um að „íslenska kerfið stæði sig ágætlega í alpjóðlegum samanburði. Prátt fyrir að heilbrigðisútgjöld væru í lægri kantinum, eða um 8,7\% af landsframleiðslu, værum við að fá mikið virði fyrir peninginn.“ Honum pótti pó íslenska kerfið illa samhæft. „Íslenska kerfið fengi gullverðlaun fyrir pað hversu einangraðar heilbrigðisstofnanirnar eru”. „Afleiðingarnar af illa samhæfðu kerfi sem nýtur lítils trausts er að fólk bíður á sjúkrahúsum af röngum ástæðum, fólk bíður of lengi eftir aðgerðum og pað kostar kerfið meiri tíma, peninga og álag." Aðspurður um hans fyrstu verk ef hann gegndi stöðu heilbrigðisráðherra á Íslandi taldi hann upp prjú atriði: „Ég myndi búa til framsæknasta heilbrigðiskerfi í heimi par sem sjúklingar væru mikilvægari en stofnanir. Í fyrsta lagi myndi ég kortleggja heilbrigði almennings, í öðru lagi endurskipuleggja umönnun aldraðra og í priðja lagi brjóta niður veggi milli heilbrigðisstofnana."

Mér pykja orð Britnells vera skynsamleg. Við verðum að forgangsraða rétt og hlúa vel að peim sterka mannauði sem við eigum í heilbrigðiskerfinu. Kannski tekst okkur pá að skapa á Íslandi framsæknasta heilbrigðiskerfi í heimi.

\section{Heimildir}

1. Upplýsingar frá flæðisdeild Landspítala.

2. „Segir heilbrigðisyfirvöld á rangri braut”. 21. júní 2017. mbl.is

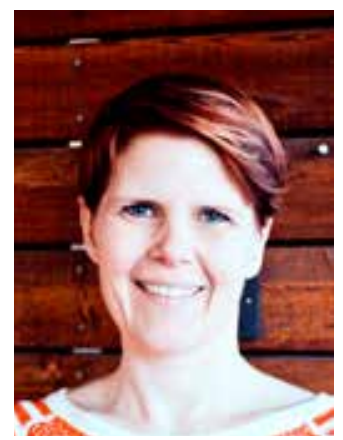

\section{Pórhildur}

\section{Kristinsdóttir}

sérfræðingur í lyflækningum, öldrunarog líknarlækningum á Landspítala

thorhikr@landspitali.is

\section{Weaknesses of the icelandic health care system}

Thorhildur Kristinsdottir, MD at Landspitali University Hospital Speciality: Internal medicine, Geriatric medicine and Palliative care 